\title{
Lapurdum
}

Euskal ikerketen aldizkaria | Revue d'études basques |

Revista de estudios vascos | Basque studies review

Numéro spécial 3 | 2015

Euskal hizkera eta dialektoak gaur egun

\section{Katalanaren bariazio sintaktikoa : ikuspegi orokorra eta kasu zehatzak}

\section{Anna Pineda}

\section{(2) OpenEdition \\ Journals}

Édition électronique

URL : http://journals.openedition.org/lapurdum/2670

DOI : $10.4000 /$ lapurdum. 2670

ISSN : 1965-0655

\section{Éditeur}

IKER

Édition imprimée

Date de publication : 1 novembre 2015

Pagination : 207-234

ISBN : 9782955341322

ISSN : $1273-3830$

Référence électronique

Anna Pineda, « Katalanaren bariazio sintaktikoa : ikuspegi orokorra eta kasu zehatzak », Lapurdum [Linean], Numéro spécial 3 | 2015, Sarean emana----an 12 juillet 2017, kontsultatu 01 mai 2019. URL http://journals.openedition.org/lapurdum/2670 ; DOI : 10.4000/lapurdum.2670 


\title{
Katalanaren bariazio sintaktikoa: ikuspegi orokorra eta kasu zehatzak
}

\author{
Anna PINEDA ${ }^{1}$ \\ Universitat Autònoma de Barcelona
}

\section{Laburpena}

Artikulu honetan katalanaren bariazio sintaktikoa izango dugu hizpide. Katalanaren dialektoen deskribapen orokorra emango dugu, eta aldakortasunaren kasu zehatz batzuk aztertuko ditugu, hala nola, ezeztapena, aditz laguntzaileak eta datibo/akusatibo alternantziak. Bestalde, euskara eta katalana alderatuko ditugu, eta ikusiko dugunez, katalanez agertzen diren fenomeno aldakor batzuk, alternantziak adibidez, euskaran ere agertzen dira.

\section{Katalana eta euskara: minorizatuak, baina desberdinak}

Artikulu honetan katalanaren bariazio sintaktikoa izango dugu hizpide. Lehenik eta behin euskara eta katalana alderatu nahi genituzke, ez hizkuntza bera, baizik eta egoera soziolinguistikoa. Bi hizkuntza minorizaturen aurrean gaude baina, aldi berean, bi egoera desberdinen aurrean.

1. Lan honek bi ikerketa proiekturen laguntza jaso du, FFI22011-29440-C03-03 (Ministerio de Educación) eta 2014 SGR 1013 (Generalitat de Catalunya). Goretti Altzuriri, orain dela urte batzuk Bartzelonan nire euskara irakaslea izan zenari eta, garrantzitsuago, gaur egun nire lagunik onenetako bat denari, eskerrak eman nahi dizkiot testua zuzentzeagatik eta hizkuntzaren erabilera asko hobetzeagatik. 
Bi hizkuntzen arteko konparazioarekin hasi ahal izateko, ikus dezagun Herrialde Katalanetako mapa hau:

Bistan da mapa honek lurralde desberdinak hartzen dituela bere baitan: Katalunia, Ipar Katalunia (Frantzian), Andorra (katalana hizkuntz ofizial bakarra den estatu independentea), Aragoiko Zerrenda, Herrialde Valentziarra, El Carxe (Murtzian), Balear Uharteak eta LAlguer (Sardinian, Italian). Guztira ia hamalau milioi biztanle daude: zazpi milioi Katalunian, ehun mila Ipar Katalunian, hogeita hamabost mila Andorran, berrogeita hamar mila Aragoiko Zerrendan, lau milioi Herrialde Valentziarrean, mila El Carxe-n, milioi bat Balear Uharteetan eta berrogei mila L'Alguer-en.

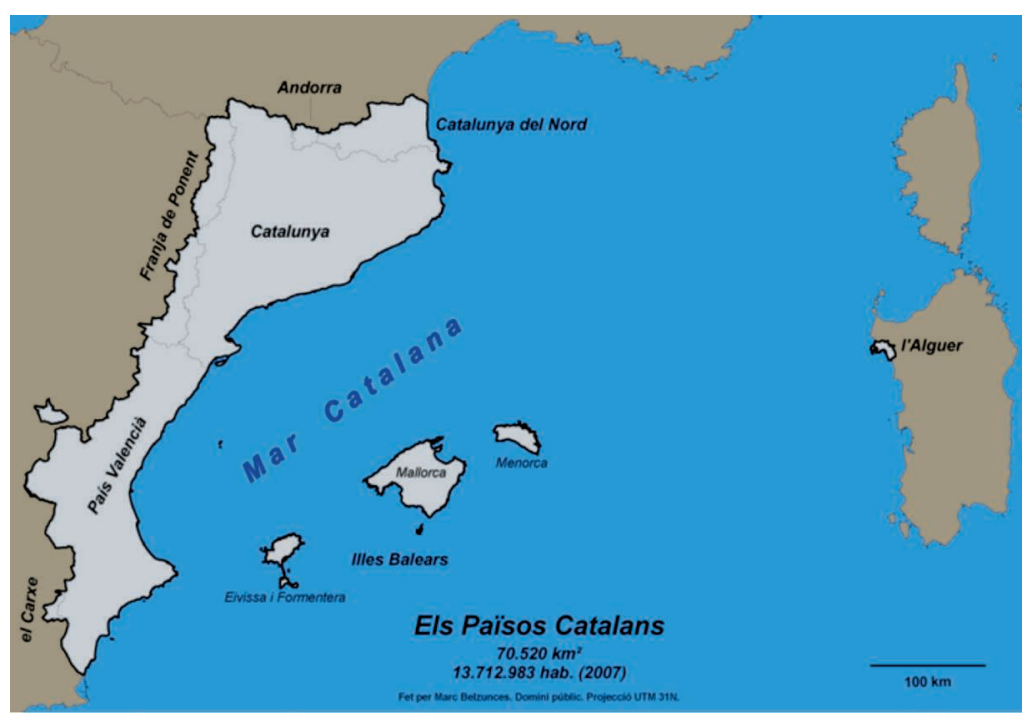

Taula honetan katalanaren ezagutzaren inguruko datu estatistiko batzuk ikus ditzakegu. 2013. urteko datuak dira eta Kataluniari dagozkio.

Creixen les capacitats de parlar i llegir en català.

A Catalunya, en nombres absoluts hi ha gairebé 5.900 .000 persones de 15 anys $i$ més que entenen el català, 5.027 .200

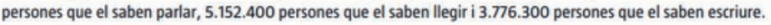

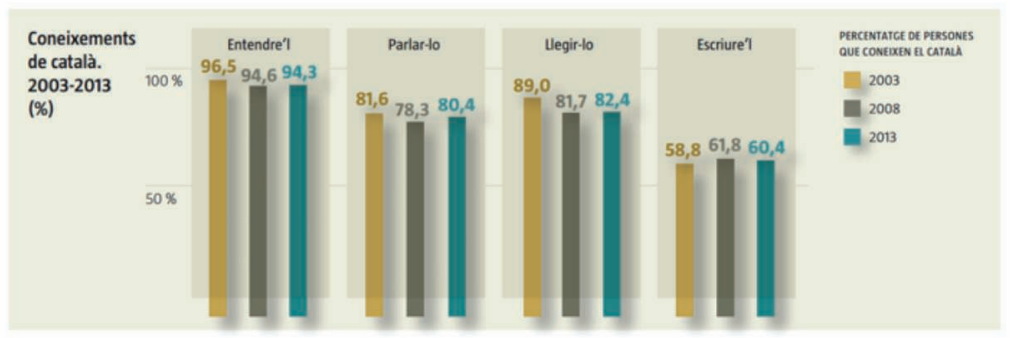

(Generalitat de Catalunya 2013: 5) 
Gure ustez, goiko taulatik ondorioztatu daitekeen daturik garrantzitsuenetariko bat katalanaren ulermenarena da. Datu hauen arabera, Kataluniako biztanleen ehuneko laurogeita hamabostek katalana ulertzen du, beraz, esan ahal da kalean ia mundu guztiak ulertzen duela katalana. Zentzu honetan, euskararekin alderatuz, egoera soziolinguistikoa oso bestelakoa da. Jakina, guk abantaila txiki bat daukagu: gure hizkuntza erromanikoa da, gaztelania bezala, beraz ulermena askoz errazagoa da.

Beheko grafiko hauek ere interesgarriak izan daitezke:

\section{Ús del català com a llengua habitual. 2013}

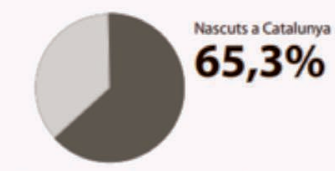

Font: Idescat i Depertament de Cultura.
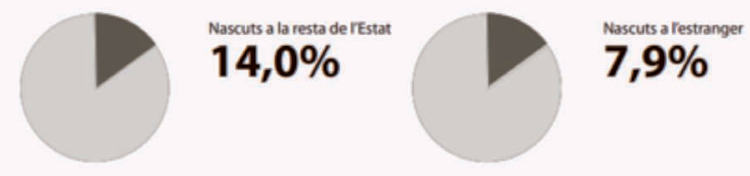

(Idescat 2014: 3)

Ikus daitekeenez, Katalunian jaiotako pertsonen artean, ehuneko hirurogeita bostentzat ohiko hizkuntza katalana da, Espainian jaio direnen artean, berriz, ehuneko hamalaurentzat eta, azkenik, atzerrian jaiotakoen artean ehuneko zortzik du katalana ohiko hizkuntzatzat.

Adierazgarria den beste datu bat da katalanak lan munduan duen presentziarena. Lehenengo zutabean ikus daiteke erabilera nahiko altua dela.

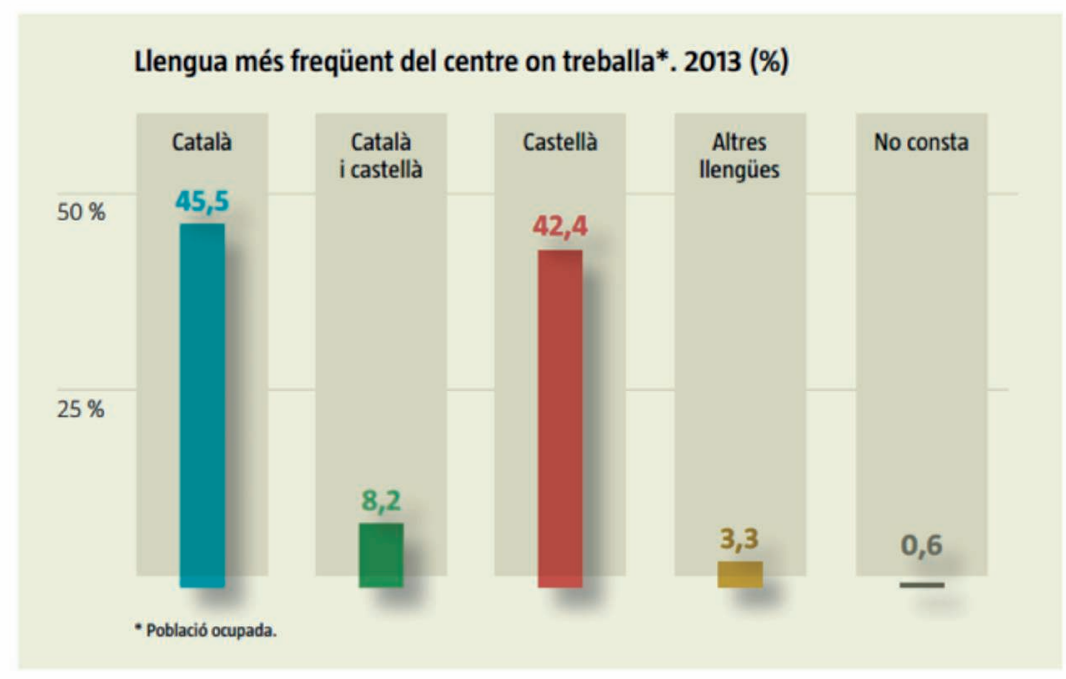

(Generalitat de Catalunya 2013: 10) 
Orain arteko datuak Kataluniari soilik zegozkion. Hona hemen Herrialde Katalanak kontuan hartuta ateratako datu estatistikoak:

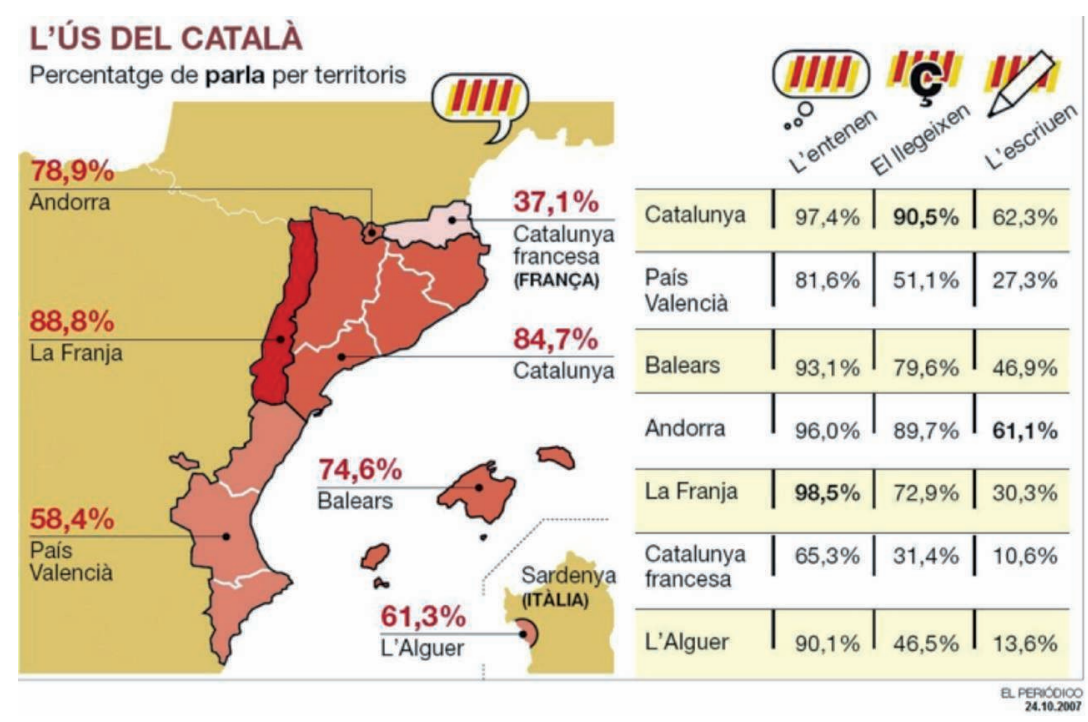

(El Periódico, 2007.10.24)

Zaharragoak dira, 2007. urtekoak, baina mapan dauden ehunekoak begiratuz gero, ideia orokor bat izango dugu. Katalana Katalunian asko erabiltzen dela argi ikusten da, baina egia da Katalunian bertan ere errealitate desberdinak daudela: ez du zerikusirik erdialdean dauden herrien errealitateak Bartzelona inguruan dauden hirienarekin.

Kuriosoa da era berean, Aragoiko Zerrenda izatea katalana gehien hitz egiten den lekua. Eta noski, Ipar Katalunian, Estatu Frantsesen, dugu egoerarik okerrena.

Aurkezpen soziolinguistiko labur hau egin ondoren, katalanaren dialektoei buruz jardungo dugu.

\section{Katalanaren dialektoak}

Katalanaren dialektoak bi bloke handitan banatzen dira: català occidental edo mendebaldekoa eta català oriental edo ekialdekoa: 


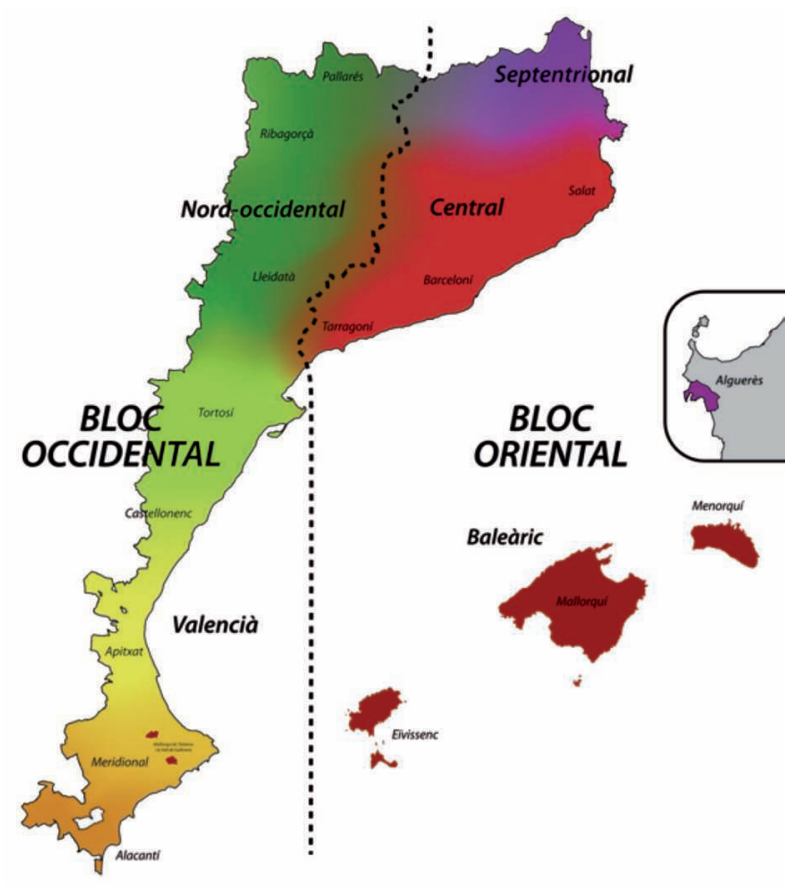

Banaketa hau egiteko kontuan hartu den ezaugarria fonetikoa izan da, a eta $e$ bokal azentugabeen ahoskera, hain zuzen ere. Ekialdeko katalanez biak [ə] ahoskatzen dira, eta mendebaldeko katalanez, gaztelaniaz bezala, a [a] da, eta e [e] da. Banaketa hau Milà i Fontanalsek proposatu zuen hemezortzigarren mendean (Milà i Fontanals 1861), eta ondotik Pompeu Fabrak eta Joan Veny-ek baieztatuta izan da.

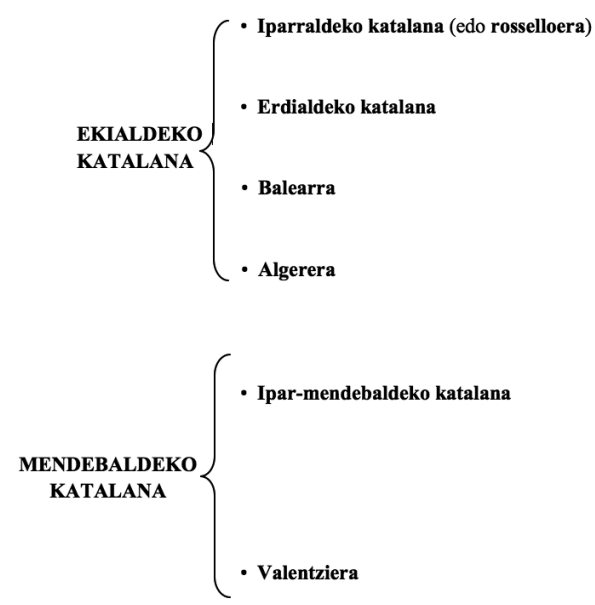


Hurrengo mapan ikus daiteke bakoitza non hitz egiten den:

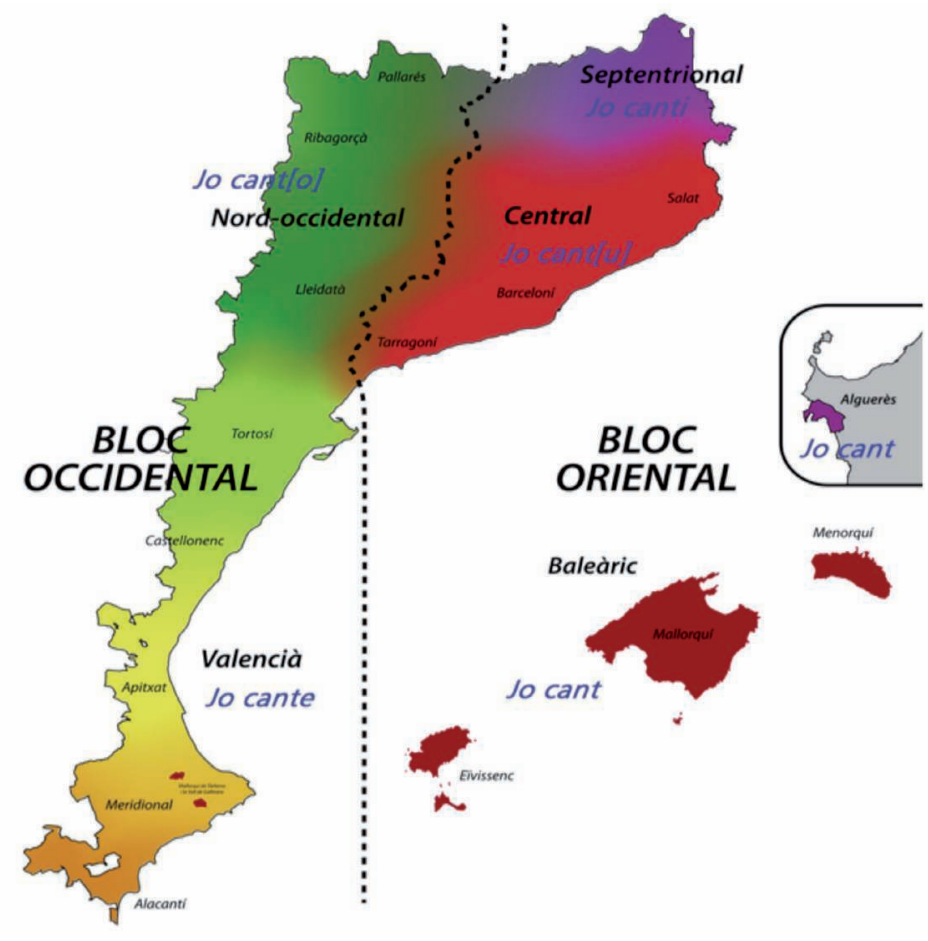

Lehen aipatu dugu bi bloke handiak bereizterakoan ezaugarri fonetiko baten arabera egin zela banaketa. Dialektoen kasuan, berriz, ezaugarri erdi morfologiko eta erdi fonetikoa hartu da kontuan: orainaldiko lehenengo pertsona singularra. Erdialdeko katalanez, jo cant [u] esaten da; ipar-mendebaldeko katalanez, jo cant [o]; iparraldeko katalanez, rosselloeraz, jo cant [i]; valentzieraz, jo cant [e]; balearrez, jo cant; eta algereraz ere, jo cant.

Banaketarekin jarraituz, sei dialektoek hainbat azpidialekto hartzen dituzte beren baitan: 


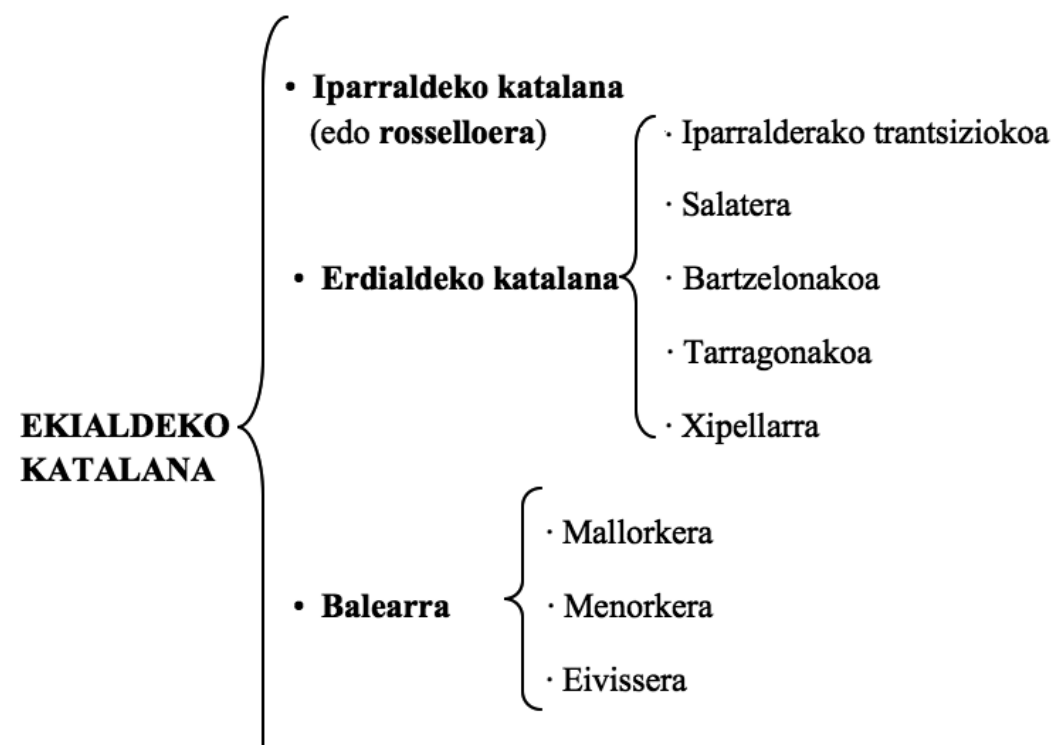

- Algerera

$\underset{\text { KATALANA }}{\text { MENDEBALDEKO }}\left\{\begin{array}{l}\text { Ipar-mendebaldeko katalana }\left\{\begin{array}{l}\cdot \text { Ribagorzarra } \\ \cdot \text { Pallarera } \\ \cdot \text { Tortosiera }\end{array}\right. \\ \cdot \text { Valentziera }\left\{\begin{array}{l}\cdot \text { Iparraldeko valentziera } \\ \cdot \text { Erdialdeko valentziera (edo apitxat }) \\ \cdot \text { Hegoaldeko valentziera }\end{array}\right.\end{array}\right.$ 
Panorama orokorra ikusi ondoren, beste ikuspegi batetik ere begiratzen ahal dugu. Hogeita hamarreko hamarkadan Italiako hizkuntzalari batzuek linguistica areale-ri buruz hitz egin zuten: alderdi nagusiak, bazterrekoak eta isolatuak bereizten zituzten.

Gure kasuan, ikuspuntu honen arabera, erdialdeko katalana litzateke alderdi nagusia, valentziera eta balearra bazterrekoak, eta pallarera (Pirinioetan) alderdi isolatua. Hala ere, beste alderdiekin duen kontaktu urria dela eta, Balearra ere isolatutzat har dezakegu. Bestalde, desagertzear dagoenik ere badugu gurean: algerera (Sardinian) eta salatera (Costa Bravako herri batzuetan erabiltzen da, es eta sa erabiltzen dituzte artikulu gisa, adibidez el cotxe esateko, es cotxo esaten dute; edo la casa esateko, sa casa).

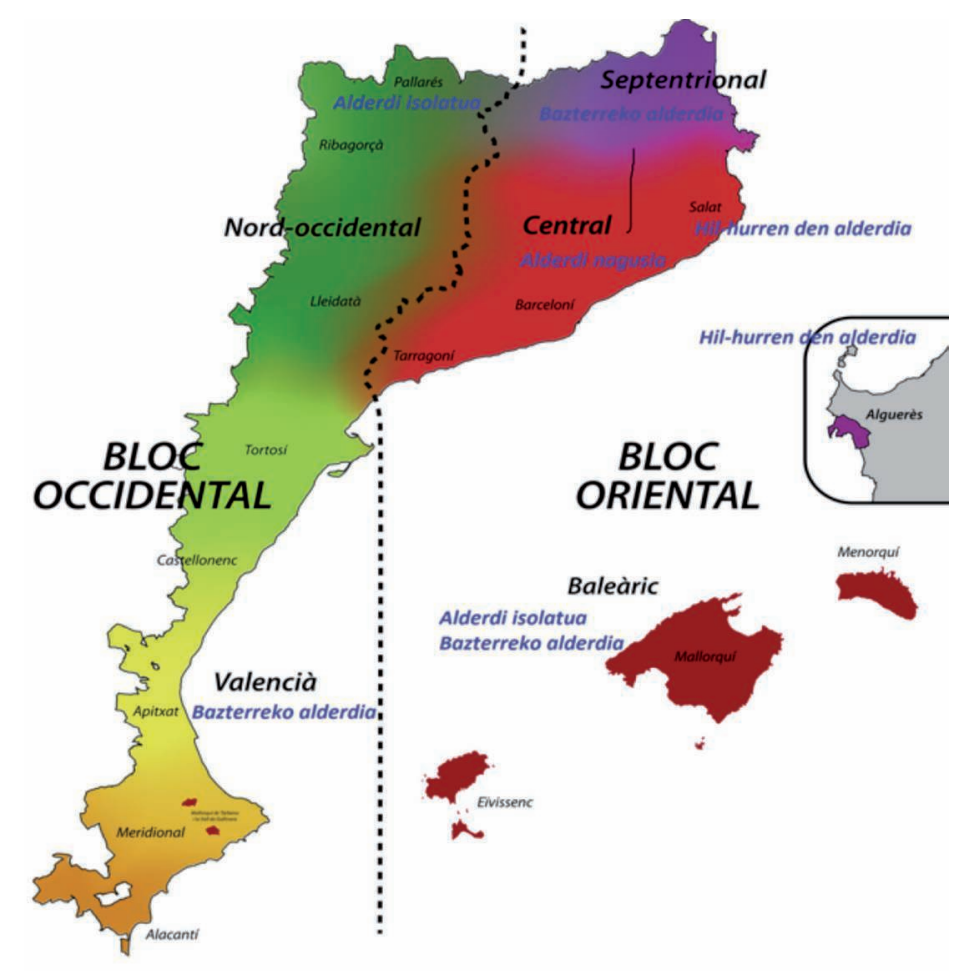

Azkenik, interesgarria da ikustea alde nagusia berritzailea dela, eta bazterreko alderdiak eta alderdi isolatuak, aldiz, kontserbadoreak. Hurrengo atalean egiaztatuko dugu hau, bariazio sintaktikoak aipatzerakoan. 


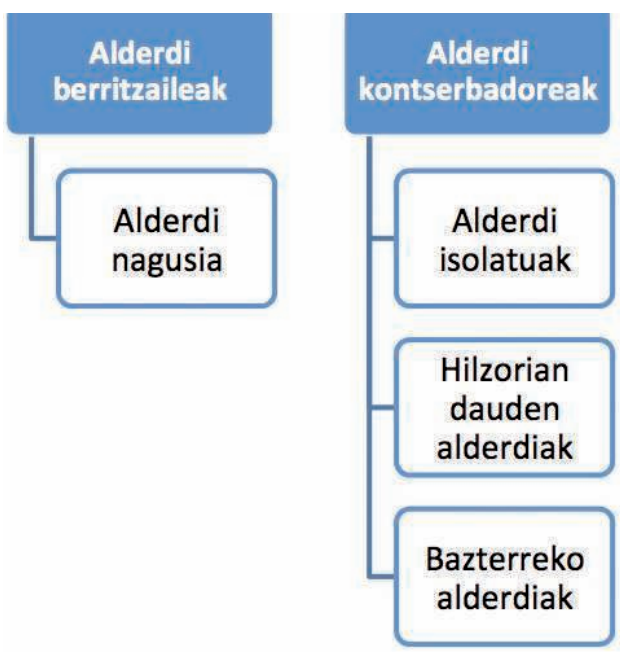

\section{Bariazio sintaktikoa}

Zergatik da interesgarria bariazio sintaktikoa ikertzea? Dialektologia tradizionalean, hizkuntza guztietan, sintaxia oso gutxi aztertu izan da. Katalanaren kasuan, Gemma Rigau Kataluniako hizkuntzalariak honela dio:

«La dialectologia catalana compta amb un repertori bibliogràific força extens, però, per desgràcia, no disposem de monografies ni d'atles que situïn els estudis sobre la variació sintàctica al nivell dels estudis sobre la variació dialectal fonètica, lèxica o morfològica. El cert és que sabem ben poca cosa sobre la variació sintàctica del català.»

['Dialektologia katalanakerrepertorio bibliografiko oparoa du, baina, zoritxarrez, ez dugu ez monografiarik ez atlasik bariazio sintaktikoari buruzko ikerketak bariazio dialektal, fonetiko, lexiko edo morfologikoekin parekatzen dituenik. Oso gutxi dakigu katalanaren bariazio sintaktikoari buruz.']

(Rigau 1998: 78-79)

Momentu honetan, hala ere, gero eta gehiago aztertzen ari den gaia da hau. Orain ikusiko dugu bariazio sintaktikoa non dagoen.

Bereziki lau puntu aztertuko ditugu: ezeztapena (4.1. atalean), laguntzaileak (4.2. atalean), komunztadura aditz inakusatiboekin (4.3. atalean) eta datibo/akusatibo alternantziak (4.4. atalean). Jakina, beste batzuk ere badaude, baina oraingo honetan interesgarrienetariko batzuk aukeratu ditugu. 


\section{Kasu zehatzak}

\subsection{Ezeztapena (enfatikoa)}

Katalanez, ezeztapen enfatikoa adierazteko aukera desberdinak dauzkagu. Ikus dezagun adibide bat: 'Inola ere ez naiz etorriko'. Ipar-mendebaldeko katalanez eta erdialdeko katalanez, No vindré pas esaten da. Iparraldeko katalanez (rosselloeraz), berriz, Vindré pas (no adberbiorik gabe) erabiltzen dute. Iparralderako trantsiziokoan beste egitura bat dago: Poc que vindré edo Pla que vindré. Pirineotan, pallareraz, No vindré cap edo Vindré cap esaten da. Azkenik, beste alderdietan, ez dago partikularik enfasia adierazteko.

Mapa honetan aukera guztiak ageri dira:

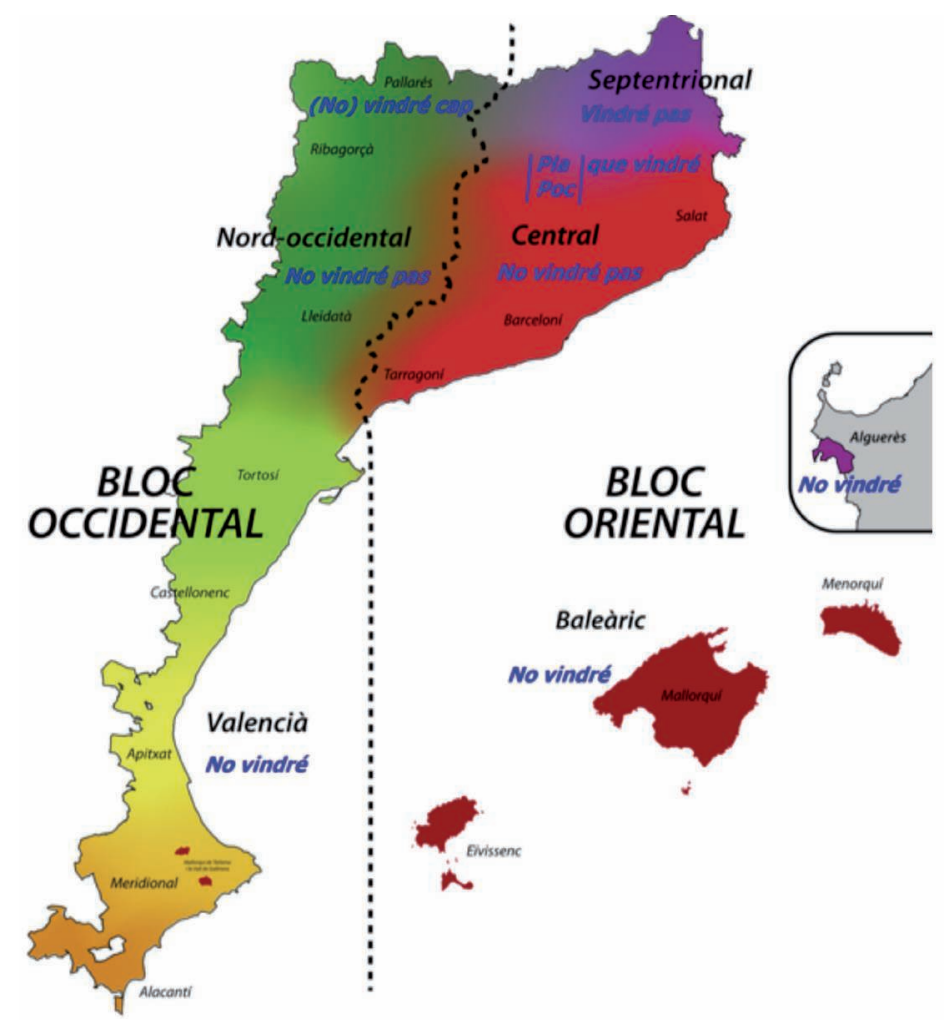

Lehen begiratuan, lexiko kontu soil bat dela pentsa genezake, hitz desberdinak (pas, poc, pla, cap) agertzen direlako. Baina hori baino gehiago da, egitura bakoitzak ezaugarri sintaktiko, banatzaile eta semantiko desberdinak baititu, eta ikusiko dugun bezala, aukera bakoitza gramatikalizazioaren edo berranalisiaren gradu desberdin baten irudia da. Beraz, bariazio sintaktikoa da. 
Gai hau gainetik baino ez dugu azalduko, baina irakurleak informazio gehiago nahi izanez gero, Llop-en lana (2016, prestatzen) kontsultatu ahal du, berak gai hau oso sakon aztertzen du eta.

Gorago aipatu bezala, aukera bakoitzak egitura sintaktiko desberdina du. Hona hemen hori argiago ikusteko esaldi egitura sinplifikatu bat:

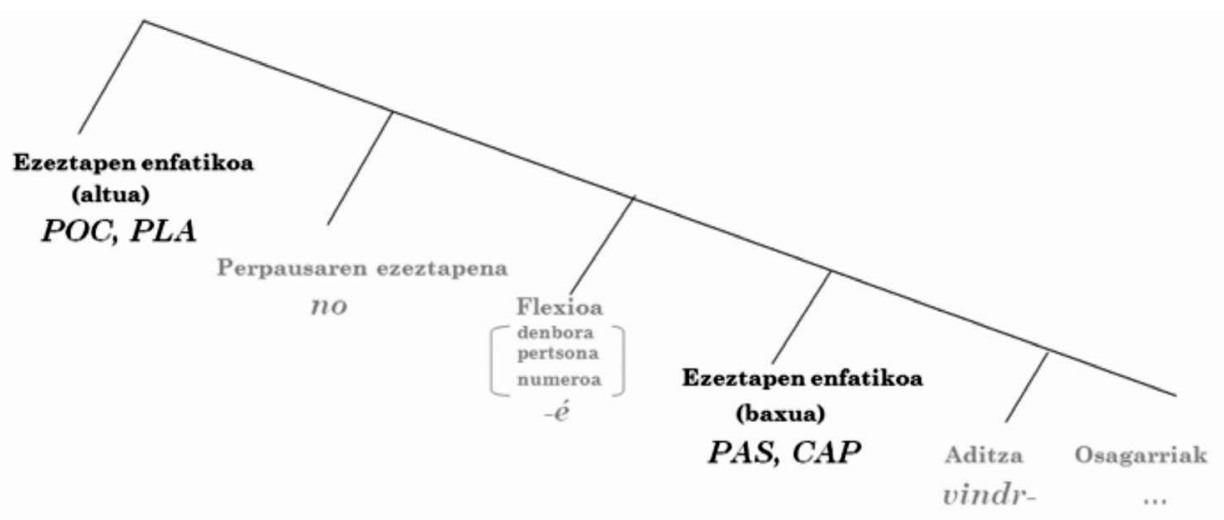

Ikus daitekeenez, aditza behean daukagu eta flexioa gorago (hizkuntzalariek aditzerroa mugitzen dela uste dute). Adibidez, No vindré pas eta Vindré pas aukerak ezeztapen enfatiko baxuaren kasuak dira, aditzaren eta flexioaren artean daudenak. Aurreko mapan ikusi dugu No vindré pas erdialdeko katalanean eta ipar-mendebaldekoan erabiltzen dela. Vindré pas, berriz, iparraldeko katalanaren aukera da.

(No) vindré cap ere ezeztapen enfatiko baxua da. Aukera hau ipar-mendebaldeko katalanari dagokio, ribagorzarrez eta pallareraz erabiltzen da zehazki.

Bestalde, Poc/Pla que vindré ezeztapen enfatiko altua da. Perpaus osoari eragiten dio, modu berezi bat da. Aukera hau erdiko katalanean aurkitzen dugu, iparralderako trantsizioko hizkeran, hain zuzen ere.

Llop-ek (2016, prestatzen) oso ondo azaltzen duenez, aukera guztien artean dauden desberdintasunak ez dira egiturakoak bakarrik. Esan dugun bezala, aukera bakoitzak gramatikalizazio gradu desberdina du. Izan ere, enfasi seinaleen jatorria gramatikalizazio prozesu bat da. Honi Jespersen-en zikloa deitzen zaio, Jespersen izena zuen hizkuntzalari batek ikertu zuelako. Ideia orokorra da ezeztapen markak berranalizatzen direla, hau da, esanahi desberdinak lortzen dituztela. Prozesu hau ikusiko dugu orain, frantsesaren historian gertatu dena erreferentziatzat hartuta: 
Jespersen-en zikloa (1917): ezeztapenaren marken berranalisia

1. fasea NEG + ADITZA

Je NE sais 'Ez dakit' $\Rightarrow$ Valentziera, balearra, algerera

2. fasea NEG + ADITZA + ERREFORTZUA (enfasia adierazteko)

Je NE sais (PAS) $\Rightarrow$ Erdialdeko eta ipar-mendebaldeko katalana

3. fasea NEG + ADITZA + ERREFORTZUA (derrigorrezkoa)

Je NE sais PAS $\Rightarrow$ Ipar-mendebaldekoa (ribagorzarra eta pallarera)

\section{4. fasea ADITZA + ERREFORTZUA (derrigorrezkoa)}

Je sais PAS $\Rightarrow$ Iparraldeko katalana

Lehenengo fasean, ezeztapena eta aditza dauzkagu. Adibidez, Je NE sais 'Ez dakit'. Katalanaren dialektoen kasuan, egoera hau valentzieraz, balearrez eta algereraz aurkitzen dugu.

Bigarren fasean, ezeztapena eta aditza ditugu, eta errefortzu bat gehitzen dugu enfasia adierazi nahi baldin badugu. Adibidez, Je NE sais (PAS). Hau da erdialdeko eta iparmendebaldeko katalanez gaur egun gertatzen dena: hiztunak, enfasia adierazi nahi baldin badu, pas erabiliko du, ez ordea, ezeztapen arrunt bat baldin bada.

Hirugarren fasean, errefortzua ez da aukerakoa, baizik eta derrigorrezkoa. Adibidez, frantsesez, gaur egun, ezeztapen arrunt bat adierazteko Je NE sais PAS esaten da. Hau da ribagorzarrez eta pallareraz gaur egun gertatzen dena, cap errefortzua (No vindré cap) beti erabili behar da.

Azkenik, laugarren fasean, ezeztapen marka, no, jadanik ez da beharrezkoa. Adibidez, frantsesez, hizkera arrunta baldin bada, Je sais PAS esaten da. Hau da iparraldeko katalanean gertatzen dena: Vindré pas esaten da.

Ezeztapenarekin bukatzeko, galdera batzuk egin ahal ditugu. Adibidez, nola adierazten da enfasia aipatu ez ditugun dialektoetan? Mapan ikusten den bezala, valentzieraz, balearrez eta algereraz ez dago errefortzurik: 


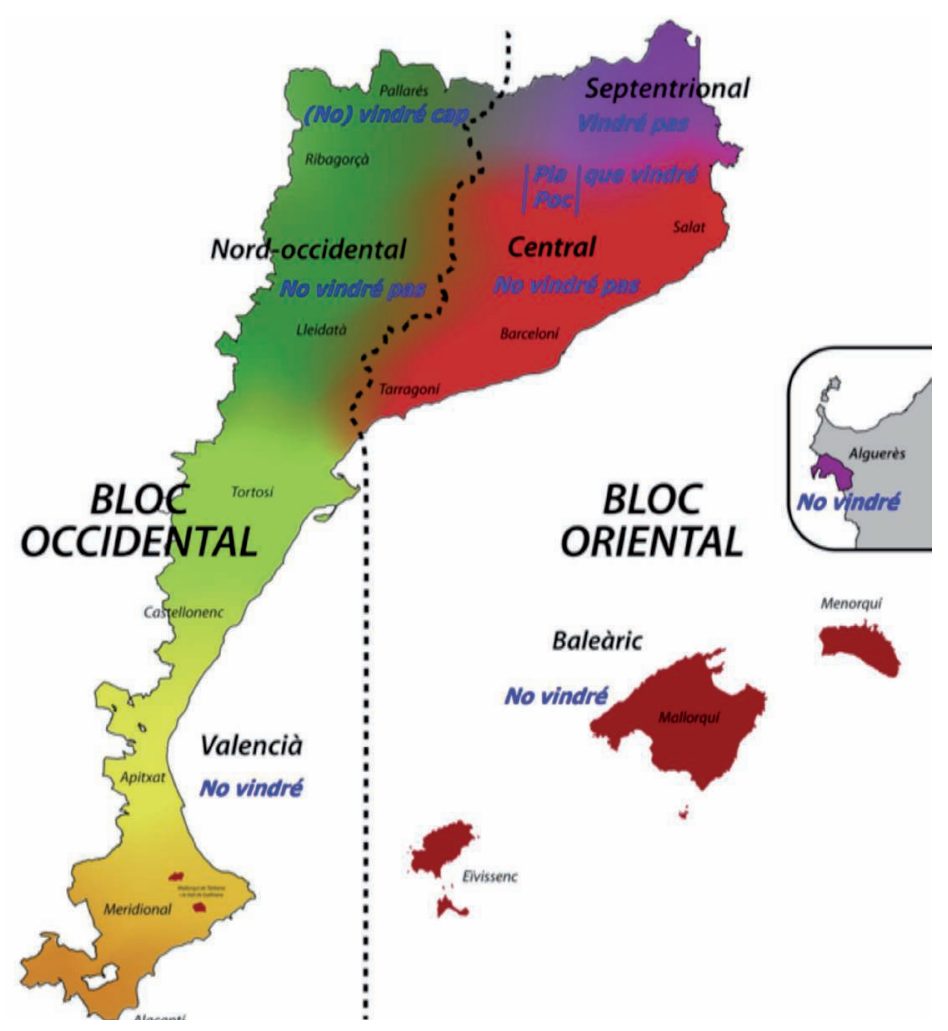

Galdera hau Llop-en lanak erantzungo du, ziur. Posible da dialekto hauetan beste estrategiak erabiltzea gauza bera adierazteko: adibidez en absolut 'inola ere, ezer(txo) ere', edo per a res 'batere'.

Llop-ek lantzen dituen beste alderdi batzuk, pas markarekin lotuta dute. Kontua da kokapen bat baino gehiago dituela partikula honek. Honela, aditz-gune barruan, No ha vingut PAS edo No ha PAS vingut ('Ez da etorri') esan daiteke. Gainera, berregituraketa-predikatu barruan, hau da, nahi eta beste aditz batzuekin, aukera bat baino gehiago dago; eta honez gain klitikoak edo izenordainak baldin badaude, oraindik aukera gehiago: No ho vol PAS fer / No ho vol fer PAS / No vol PAS fer-ho / No vol fer-ho PAS ('Ez du egin nahi'). Bukatzeko, menpeko moduzko perpausetan ere aukera desberdinak daude: No volia PAS que vingués edo No volia que vingués ('Ez zuen nahi bera etortzea').

Honekin bukatuko dugu ezeztapenari eskainitako atala. Hasieran esan bezala, gai hau interesatzen zaion irakurleak, Llop-en lana kontsultatu ahalko du. 


\subsection{Laguntzaileak}

Atal honetan aditzei buruz ariko gara, laguntzaileei buruz zehazki. Euskal hiztunek ongi dakitenez, bi laguntzaile daude: euskararen kasuan, edun eta izan; hizkuntza erromanikoen kasuan, HABERE eta ESSERE latinezko aditzen oinordekoak (katalanaren kasuan, haver eta ser).

Taulan ikusten da euskaraz eta frantsesez bereizketa hau egiten dela, katalan estandarrean, aldiz, ez da horrelakorik egiten, beti haver erabiltzen da:

\begin{tabular}{|l|l|l|l|}
\hline \multirow{2}{*}{} & \multicolumn{1}{|c}{$\begin{array}{c}\text { Aditz } \\
\text { iragankorrak }\end{array}$} & Aditz iragangaitzak \\
\cline { 3 - 4 } & & inergatiboak & inakusatiboak \\
\hline Euskara & Gizon bat ikusi dut & Hitz egin dut & Etorri naiz \\
\hline Frantsesa & J'ai vu un homme & J'ai parlé & Je suis venu \\
\hline $\begin{array}{l}\text { Katalana } \\
\text { estandarra }\end{array}$ & He vist un home & He parlat & He vingut \\
\hline $\begin{array}{l}\text { Katalana } \\
\text { balearra }\end{array}$ & He vist un home & He parlat & Som vengut \\
\hline $\begin{array}{l}\text { Katalana } \\
\text { algerera }\end{array}$ & He vist un home & He parlat & Só vengut \\
\hline $\begin{array}{l}\text { Katalana } \\
\text { iparralderako } \\
\text { trantsiziokoa }\end{array}$ & HelSom vist un home & He parlat & Som vingut \\
\hline $\begin{array}{l}\text { Katalana } \\
\text { iparraldekoa } \\
\text { (rosselloera }\end{array}$ & \begin{tabular}{l} 
Som vist un home \\
\hline
\end{tabular} & He parlat & Som vingut \\
\hline
\end{tabular}

Hala ere, katalan zaharrean bai existitzen zen bereizketa hau, eta dialekto batzuk mantendu egin dute (Veny 1983, Batlle 2002). Taulan ikusten denez, mantendu dutenak bazterreko alderdiak eta alderdi isolatuak izan dira (beraz kontserbadoreak). Adibidez, Balear Uharteetan erabiltzen dute ser aditz iragangaitz inakusatiboekin, nahiz eta bereizketa galtzen ari den. Veny-ek, katalanaren dialektologo garrantzitsuenak, horrela azaltzen zuen laurogeiko hamarkadan:

«L'ús dels pretèrits composts amb l'auxiliar ésser avui només s'estén per Mallorca i Menorca (som anat, he anat, ets vengut, has vingut, etc.), però amb 
una marcada nota de rusticitat. No li queden gaire dècades de vida a aquesta construcció.»

['Gaur egun, ésser laguntzailearekin osatutako iraganaldi burutua Mallorca eta Menorcan besterik ez da erabiltzen (som anat, he anat, ets vengut, has vingut, etab.), baina txokokeri kutsu nabarmenarekin. Joskera honen erabilerak ez du luze iraunen.']

(Veny 1983: 94)

Eivissa-n, esaterako, jadanik galdu da, beharbada valentzierarekiko kontaktuagatik.

Bestalde, laguntzaileen bereizketa algereran, iparralderako trantsizioko katalanean eta iparraldeko katalanean ere mantentzen da (baina azken kasu honetan, 1. eta 2. pertsonetan bakarrik).

Hizkuntza batzuetan, aditz pronominaletan ere izan edo ser laguntzailea erabiltzen da. Gramatikako puntu honetan, euskararekin konparatzea ez da erabilgarria baina frantsesarekin, esaterako, bai.

\begin{tabular}{|l|l|l|}
\hline & \multicolumn{2}{|c|}{ Aditz pronominalak } \\
\hline Euskara & $\sim \quad$ (Hatz bat ebaki dut) & $\sim \quad$ (Min hartu dut) \\
\hline Frantsesa & Je me suis coupé un doigt & Je me suis blessé \\
\hline $\begin{array}{l}\text { Katalana } \\
\text { estandarra }\end{array}$ & M'he tallat un dit & M'he ferit \\
\hline $\begin{array}{l}\text { Katalana } \\
\text { balearra }\end{array}$ & M'he / Em som tallat un dit & M'he / Em som ferit \\
\hline $\begin{array}{l}\text { Katalana } \\
\text { algerera }\end{array}$ & Em som tallat un dit & Em som ferit \\
\hline $\begin{array}{l}\text { Katalana } \\
\text { iparralderako } \\
\text { trantsiziokoa }\end{array}$ & Em som tallat un dit & Em som ferit \\
\hline $\begin{array}{l}\text { Katalana } \\
\text { iparraldekoa } \\
\text { (rosselloera) }\end{array}$ & Em som tallat un dit & Em som ferit \\
\hline
\end{tabular}


Nahiz eta katalan estandarrak haver erabili, beste dialekto batzuk ser erabiltzen dute, katalan zaharrak bezala. Taulak erakusten duen bezala, oraingoan ere dialekto kontserbadoreak dira bereizketa mantentzen dutenak (alderdi isolatuak edo bazterreko alderdiak): balearra, algerera, iparralderako trantsiziokoa eta iparraldekoa (edo rosselloera). Kasu honetan ere, balearrean bereizketa galtzen ari da, eta iparraldeko katalanean bakarrik 1. eta 2. pertsonetan egiten da.

Ez genuke laguntzaileen gaiarekin bukatu nahi lehen aipatutako Veny-en hitzak komentatu gabe. Veny-ek adierazi zuen ser auxiliarra erabiltzeak txokokeriaren ukitua zuela. Eta egia da batzuetan hiztunek hizkerarekiko eta zehazki bariazioarekiko aurreiritziak dituztela. Adibide bat ikusiko dugu. Adineko pertsona batek idatzitako testua da, eta idazten duenak bere lagun bati buruz hitz egiten du. Biak Kataluniako herrixka batekoak dira. Idazten duena, neskatoa zenean, ondoko herri handixeago batera joan zen bizitzera, beretik 8 kilometrotara. Bere laguna herrian geratu zen eta zahartutakoan bera ere herri handiago horretara joan zen. Beraz, azkenean biak elkartu dira. Testuinguru honetan, interesgarria da ikustea zer esaten duen idazten duenak bere herrixkako lagunari buruz.

«La Pepeta Font és una amiga de la iaia. Té a prop de noranta anys. Havien viscut sempre a Santa Maria de Merlès amb una casa de pagès, sempre veïnes. La Pepeta diu que es recorda del bateig de la meva àvia. Ara, de velles, s'han tornat a trobar a Prats de Lluçanès i també al mateix carrer. La Pepeta és d'uns costums molt pagesa, diu algunes paraules que poques gent les diuen, per exemple per dir "he anat" ella diu "sóc anat" o "só anat" o "s’anat", o [per dir "he fet" diu] "só fet" o "sóc fet", [i per dir "li he dit" diu] "li sóc dit" o "li só dit"; i aixís moltes cosetes.»

['Pepeta Font amatxiren lagun bat da. Laurogehita hamar urte inguru ditu. Beti beti izan ziren Santa Maria de Merlès herriko baserri banatan, beti bizilagun. Pepetak amatxiren bataioarekin oroitzen dela esaten du. Orain, zahartuta, Prats de Lluçanès-en egin dute topo, berriro ere kale berean. Pepetak baserriko ohiturak ditu, jende gutxik esaten dituen hitz batzuk erabiltzen ditu. Adibidez, "he anat" esateko "sóc anat" edo "só anat" edota "s'anat" esaten du, edo ["he fet" esateko] "só fet" edo "sóc fet", [eta "li he dit" esatekol "li sóc dit" edo "li só dit"; eta horrela beste hainbat gauzekin.']

Zati hau interesgarria da laguntzaileetan bariazioa dagoela erakusten duelako. Irakurtzen jarraitzen baldin badugu, iruzkin soziolinguistiko edo etnolinguistikoak ere aurkituko ditugu:

«Si parlen de "la setmana passada" ella diu "la sumana"; tot aixís amb un costum molt primitiu.

A vegades diuen, ella o la iaia: "Avui dinarem d'escudella", un plat típic del país, doncs ella a vegades en diu "escatxaruta" de la manera més rústica que sap.

És estrany perquè ara fa anys que viu a Prats i va treballar uns quants anys a la fàbrica.» 
['Pasa den asteaz hitz egiten ari badira, "la setmana passada" esateko, "la sumana" esaten du; ohitura oso primitiboz.

Batzuetan, berak edo amatxik, "escudella" bazkalduko dutela komentatzen dute, hemengo plater tipiko bat. Ba berak batzuetan "escatxaruta" hitza erabiltzen du, ezagutzen duen modurik baldarrenean.

\section{lantegian lanean.']}

Arraroa da, urte asko baitaramatza Pratsen eta gainera urte batzuk pasa zituen

Hona hemen testu originala:

La Repeta Font, es mua amiga de la ivata, te aprop de noranta anap, harisen virseat semppre a $f=$ Maria de Morles unb una casa de prages sempre veinos, la Bepeta din que is recarda di et vateix de la marve avias, ara de velles, han torbmat a trovar a Prots de Slucanesi tamve al nateix carrer la Pepreta es dims costiuns malt pregesersa, din algunes prarantles que progues gent les dimen, per exemplen prer dir he auat, ella diu soc anat o s'conat. o rafet o soc fet li he dit li roc dit o li rodit, i aixix moltes cosates, si parleu de la remana paradx ella dim la sumana tot ávis amb un costum moltprimutin, Aregadas diean ella ola iana avein dimarem drescodalla un plat tipic diel país dounes elle avegades en dire escatrearnta de la momara mes rustica que sap. is estrany parque arre fa onys que vim a Prato i va travaller usaes vecuis anys a la fobrica 


\subsection{Komunztadura aditz inakusatiboekin}

Katalanez bariazio sintaktikoa aditzaren eta subjektuaren arteko komunztaduran ere aurkitzen dugu. Zehazki, aditz inakusatiboekin. Eta bereziki, ipar-mendebaldeko katalanean:

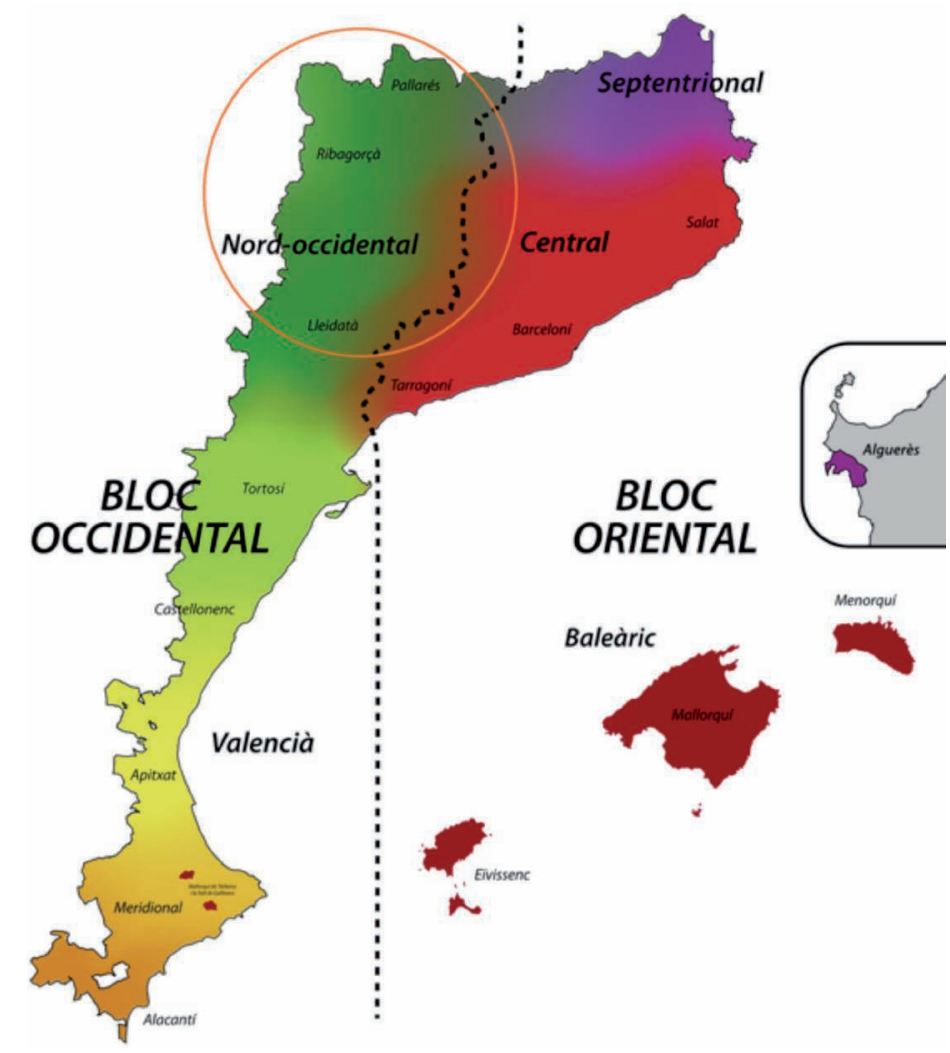

Azal dezagun lehenik zeintzuk diren aditz inakusatiboak. Esan ahal da aditz inakusatiboak egoera-aldaketa adierazten dutenak direla: adibidez, joan, etorri, jaio, hil... Ipar-mendebaldeko katalanez, aditz hauek subjektu plural eta zehaztugabe batekin agertzen direnean, ez dute aditzarekin komunztadurarik erakusten: ${ }^{2}$

2. Glosetan erabiliko ditudan laburpenak hauek dira: AKUS 'akusatiboa', ART 'artikulua', AGIN 'agintera', DAT 'datiboa', IRAG.BG 'iraganaldi burutugabea', IZENORD.ERL 'izenordain erlatiboa', MEND 'menderagailua', LOK 'lokatiboa', ORAIN 'orainaldia', PREP 'preposizioa', ORAIN. BUR 'orainaldi burutua', sG 'singularra', suBj 'subjuntiboa', PL 'plurala'. 
(1)
a. Neix nens
jaio-ORAIN.3SG Ume-PL
Jaiotzen "da" umeak
(ipar-mendebaldekoa)
b. Neixen nens
(gainerako hizkerak) jaio-oraIn.3PL ume-PL
Jaiotzen dira umeak

(2)
a. Arriba trens (ipar-mendebaldekoa)
ailegatu-ORAIN.3SG tren-PL
Ailegatzen "da" trenak
b. Arriben trens (gainerako hizkerak)
ailegatu-ORAIN.3PL tren-PL
Ailegatzen dira trenak

Azalpena da aditz hauekin, inakusatiboekin, ipar-mendebaldeko katalanez ez dagoela komunztadurarik subjektua objektu zuzen gisa hartzen delako. Hau ez da dena: batzuetan inakusatiboak ez diren aditzekin gauza bera gertatzen da. Adibidez, inergatiboa izena duen aditz bat baldin badaukagu, treballar bezala, ekintza bat adierazten da:
(3) Les dones treballen a la fàbrica ART.PL emakume-PL lan egin.ORAIN.3PL PREP ART lantegi
Emakumeek lan egiten dute lantegian

Baina aditz inergatibo hau inakusatibizatu ahal dugu. Hori egiteko, lokatibo bat (hi izenordaina) gehitu behar dugu, orduan aditzak ez du ekintza bat adierazten, baizik eta egoera bat, existentzia. Transformazio hau hizkuntzalari askok aztertu dute, batez ere Solà-k (1987, 1973 , 1994, 1999) eta Rigau-k (1992, 1997a, 1997b). Kasu honetan, ipar-mendebaldeko katalanez, komunztadura gabe egingo dute (4a), baina beste dialektoetan komunztadurarekin (4b):
a. A la fàbrica hi treballa dones (ipar-mendebaldekoa) Lantegian KL.LOK lan egin.ORAIN.3sG emakume-PL Lantegian badaude emakumeak lan egiten "duenak"
b. A la fàbrica hi treballen dones (gainerako hizkerak) PREP ART lantegia KL.LOK lan egin.ORAIN.3PL emakume-PL Lantegian badaude emakumeak lan egiten dutenak

\subsection{Datibo/Akusatibo alternantziak}

Bukatzeko, datibo/akusatibo alternantzia ikusiko dugu. Izan ere, hau izan da orain arteko nire ikerketaren gai nagusi bat (Pineda 2012, 2013a,b, 2014a,b).

Hemen ikus dezakezue zein aditzetan aurkitzen den alternantzia katalanez: 
Komunikazio-transferentzia

- telefonar/trucar 'telefonoz deitu', escriure 'idatzi', contestar 'erantzun'

Jabetza-transferentzia

- pagar 'ordaindu'

- robar 'lapurtu'

$\underline{\text { Kontaktua (lato sensu) }}$

- pegar/colpejar 'jo'

· picar 'ziztatu', mossegar 'kosk egin'

. disparar 'disparatu', apuntar '(armaz) apuntatu'

· seguir 'segitu, atzetik joan', precedir 'aurretik joan', succeir 'jarraitu (tronuan...)'

\section{$\underline{\text { Gizarte-elkarregina }}$}

- servir 'zerbitzatu', ajudar 'lagundu', cridar 'errieta egin', manar 'agindu', obeir 'obeditu', entendre 'ulertu', aconsellar 'aholkatu', ensenyar 'irakatsi', mentir 'gezurra esan', penjar (al telèfon) 'eskegi', pregar/suplicar 'erregutu', xiular 'txistu egin', aplaudir 'txalo egin', lladrar 'zaunka egin'

Aditz hauek egitura tribalente batean agertu ahal dira:
Lempresari paga
ART enpresari ordain
el sou
a l' empleat
Enpresariak langileari soldata ordaintzen dio

Baina egitura bibalente batean ere, pertsona-osagarriarekin bakarrik, aurki ditzakegu. Orduan, bi aukera ditugu: datiboan (6) ala akusatiboan (7). Datiboa da aukera originala, eta akusatiboa aukera berria. Beraz, akusatibizazio prozesu bat gertatzen ari dela ematen du: 


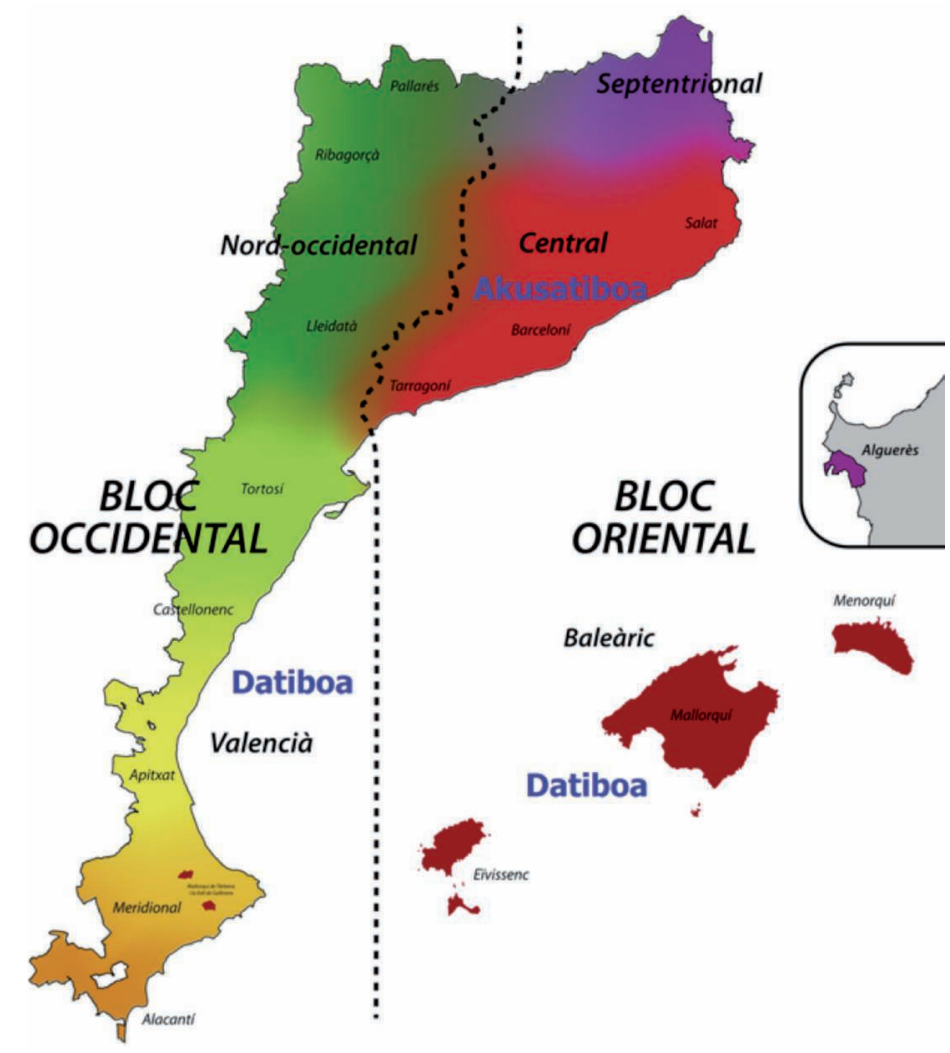

(6)
a. L'empresari paga
a l' empleat
ART enpresari ordaindu. ORAIN.3SG PREP ART langile
Enpresariak langileari ordaintzen dio
b. L'empresari li paga ART enpresari KL.3SG.DAT ordaindu.oRAIN.3SG
Enpresariak ordaintzen dio

(7)
a. Lempresari paga l' empleat ART enpresari ordaindu.ORAIN.3SG ART langile Enpresariak langilea ordaintzen $d u$
b. L'empresari el paga ART enpresari KL.3SG.AKUS ordaindu. ORAIN.3sG Enpresariak ordaintzen du

Nola banatzen da bariazioa? Ikusi ahal duzuenez, dialekto kontserbadoreetan datiboa, aukera originala, erabiltzen da. Baina erdialdeko katalanez, dialekto berritzailea dena, akusatiboa gero eta gehiago erabiltzen da (Ramos 2005a,b). Joera hau akusatibizazioa da, 
hau da, aldaketa sintaktiko bat. Aldaketa hau leku batzuetan oso aurreratua dago, eta beste batzuetan ez:

Bariazioa hurbiletik begiratzen badugu, konturatuko gara ez dela hain sinplea. Nahiz eta dauzkagun datuak sistematikoak ez izan, ondorio batzuk atera ahal ditugu: bariazioa dialektoen artean ez ezik, dialektoen barruan ere badago. Hau esateko, XIX. eta XX. mendeko idazleen literatura-korpusa (Morant 2008), eta Ramos eta Pinedak egindako inkesta informalak (Ramos 2005b, Pineda 2014b) erabili ditugu. Bertatik ateratako ondorio nagusia da hiru alderdi daudela (Pineda 2014b):

$$
\begin{aligned}
& \text { - Valentziera } \rightarrow \text { Dialekto hau aldaketarekiko erresistenteena da, datiboaren } \\
& \text { nagusitasuna dago (dialekto kontserbadorea) } \\
& \text { - Erdialdeko katalana } \rightarrow \text { Hemen gero eta zabalduago dago akusatiboa (dialekto } \\
& \text { berritzailea) } \\
& \text { - Gainerakoak } \rightarrow \text { Gainerako hizkeretan datiboa da nagusi, baina akusatiboa ere } \\
& \text { agertzen hasia da }
\end{aligned}
$$

Gainera, hiztun beraren baitan ere bariazioa egon daiteke (intraspeaker variation), hurrengo adibideak erakusten duenez:
A veure, truca-li,
truca-li, i
així sabem
Ea $b a$, deitu.AGIN-KL.DAT.3sG, deitu.AGIN-KL.DAT.3sg eta horrela jakin.PRES.1PL Ea ba, deitu berari, deitu berari eta horrela jakingo dugu
què passa. Va, truca'l!
zer gertatu.orAIN.3sG Ea, deitu.AGIN-KL.AKUS.3sG
zer gertatzen den. Ea, deitu bera!

Nola azaldu hiztun baten barruko bariazioa? Hauxe da nire proposamena: Akusatibizazioa gertatzen ari den aldaketa bat da, bukatu gabeko aldaketa. Izan ere, lau etapa daude, eta hiztun bakoitza etapa desberdin batean egon ahal da, aditzaren arabera, eta batzuetan aukerak nahasten ditu (Pineda 2014b). Orain ikusiko dugu zehatz-mehatz:

Lehenengo etapak "Hasi gabeko aldaketa" du izena. Hiztunak datiboa erabiltzen du beti (aditz jakin batekin). Hau da valentzieraren egoera (dialekto kontserbadorea): valentziera hemen geratu da, lehenengo etapan. Hiztun gehienek aditz gehienekin datiboa erabiltzen dute.

Beste dialektoak aurrerago doaz: bigarren, hirugarren eta laugarren etapetan daude (azken etapa da akusatiboa beti erabiltzea). Beraz, beste dialektoen hiztunek datiboa mantentzen dute baina aditz batzuekin bakarrik.

Bigarren etapak "Aldaketa hasiberria" du izena. Hiztunak nola datiboa hala akusatiboa erabiltzen du, aditz jakin batekin. Horrela azaltzen da lehen ikusi dugun bariazio librea: 
(9)

\author{
Aktorea: Com vols que li truqui? No la trucaré! \\ Nola nahi.izan.PRES.2SG MEND KL.DAT.3SG deitu.SUBJ.1SG \\ Nola nahi duzu nik berari deitzea? Ez dut deituko (bera)! \\ Aktorea: Truca-li. Mira, la truques \\ deitu.AGIN.2SG-KL.DAT.3SG Begira.AGIN.2sG KL.AKUS.3SG deitu.ORAIN.2sG \\ Deitu berari. Begira, zuk deituko duzu (bera) \\ i li dius que... \\ eta KL.DAT.3SG esan.ORAIN.2SG MEND \\ eta esango diozu...
}

(antzerki-lana El crèdit, Sala Villarroel, Bartzelona 2014/03/28)

Hirugarren etapak "Finkatze selektiboa" du izena. Hiztunak akusatiboa eta datiboa erabiltzen ditu, baina asmo semantikoarekin. Adibidez, robar aditzarekin, akusatiboa erabiliko du indarkeria ñabardura adierazteko:

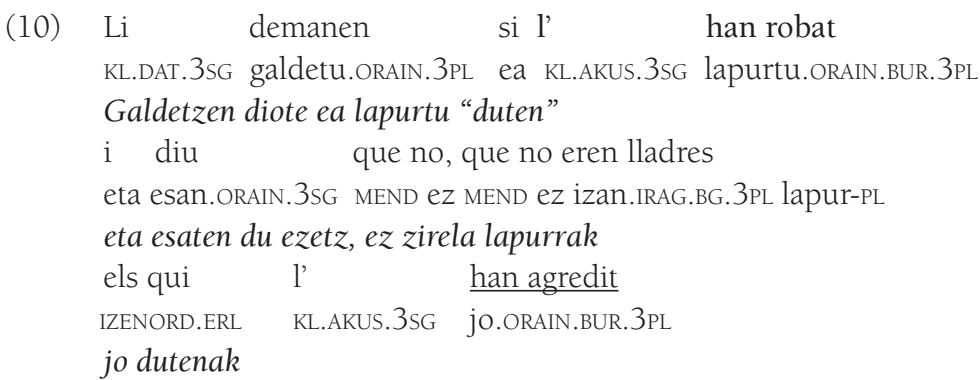

Esan behar da batzuetan aditz batzuen erabilera azaltzeko, katalan normatiboak ere horrela egiten duela. Beraz, hiztegian agertzen da aditza datiboarekin, esanahi batekin, eta aditza akusatiboarekin, beste esanahi batekin. Hurrengo bi adibideetan ikusi ahal dugu idazle berak, liburu berean, bereizte semantikoa egiten duela:

(11) -A qui vas confiar els diners? ('Nori eman zenion dirua?')

-A un home de confiança. El van matar.

PREP bat gizon PREP konfiantza. KL.AKUS.3SG hil.egin.IRAG.BUR.3PL

Konfiantzazko gizon bati. Hil egin zuten.

I el van robar.

Eta KL.AKUS.3sg lapurtu.IRAG.BUR.3PL

Eta lapurtu egin "zuten".

(12) -Vostè és un canalla. Li va robar el violí. ('Zital halakoa. Biolina lapurtu zenion') I també va robar al desgraciat Adrià Ardèvol.

Eta ere bai lapurtu.IRAG.BUR.3SG PREP+ART dohakabea Adrià Ardèvol

Eta Adrià Ardèvol dohakabeari ere lapurtu zenion.

(Jaume Cabré, Jo confesso) 
Aldaketa sintaktiko hori akusatibizaio prozesu bat denez, azken etapa da akusatiboa beti erabiltzea, nahiz eta testuingurua neutroa izan, adibide honetan ikusi ahal den bezala:

(13) - L' han robat a l' estació de tren? KL.AKUS.3sg lapurtu. ORAIN.BUR.3PL PREP ART geltoki PREP tren Lapurtu "dute" tren geltokian?

- No, a l'hotel.

- Què ha perdut?

- Unes 100 lliures.
('Ez, hotelean.')

('Zer galdu du?')

('100 bat libra.')

Hauek dira, beraz, akusatibizazio prozesuaren lau etapak.

Beste kasu batzuetan ikusi dugu katalanez agertzen diren bariazio fenomenoak beste hizkuntzetan ere agertzen direla. Berdin gertatzen da datibo/askusatibo alternantziaren kasuan ere. Adibidez, hizkuntza erromanikoetan fenomeno bera aurkitzen dugu gaztelanian (Fernández-Ordóñez 1999, Sáez 2009), asturieran (Xulio Viejo k. p.), Italiako hegoaldeko hizkeretan (Ledgeway 2000, 2009), errumanieran (Blume 1998) eta frantsesean (diakronian) (Troberg 2008, Bilous 2011). Eta beste hizkuntza-familietan ere bai: alemanieran (McFadden 2004), ukraineran (Bilous 2011) eta euskaran (Etxepare 2003, Creissels 2008, Mounole 2012, Creissels \& Mounole 2012, Fernández \& Ortiz de Urbina 2010, 2012), besteak beste.

Badirudi hizkuntza guztietan hunkitasunak zerikusia duela. Gaztelaniaz ikusiko dugun adibideari buruz (14), Inés Fernández-Ordóñez-ek honela dio: «supone una reinterpretación del verbo, aumentando su grado de transitividad e implicando un cambio de significado» eta «parece implicar que el acto de sustracción tuvo lugar en presencia del individuo afectado y con notable perjuicio del mismo».

(14) A mi madre la robaron (Ameriketakoa) PREP nire ama KL.AKUS.3SG LAPURTU.IRAG.BUR.3PL Nire "ama" lapurtu "zuen"

Euskarako adibideaz (15), berriz, Etxepare (2003) eta Odria eta Berrok (2011) esaten dute bi interpretazio izan ditzakeela:

\section{(15) Xabier bulegora deitu dute}

Lehenengoa neutrala da: "Xabier is in his office when they call/phone him there». Interpretazio hori datiboarekin ere lortzen da (Xabierri bulegora deitu diote). Bigarrenak hunkitasuna adierazten du, Xabier hunkituta izan da, leku batetik beste batera joan behar izan duelako. Odria \& Berrok honela diote: «Before the eventuality has taken place, Xabier is not in the office (he is somewhere else), and as a consequence of the deitu eventuality, Xabier has ended up in the office», hau da, «the subject has undergone a change of position, and it is therefore totally affected».

Honekin bukatzen da katalanaren bariazio sintaktikoaren panoramari buruz egin 
dugun aurkezpena.

\section{Azken gogoeta batzuk}

Ez genuke katalanaren bariazio sintaktikoari buruzko aurkezpen hau bukatu nahi gogoeta pare bat egin gabe. Artikulu honen hasieran esan dugu bariazio sintaktikoa oso gutxi aztertua izan dela. Ikus dezagun zergatik den garrantzitsua hizkuntza baten sintaxia ongi ezagutzea. Erantzuna Gemma Rigauk emango digu:

«És en la microsintaxi que podem adonar-nos de la diversitat lingüística existent entre les llengües d'una mateixa família o entre els dialectes d'una mateixa llengua. L'atenció a aquests fenòmens de microsintaxi ens pot fer visibles propietats de la llengua que ens podrien passar desapercebudes als estudiosos [...]. I més encara si aquests fenòmens són característics de la parla col-loquial.»

['Bariazio sintaktikoetan konturatu ahal gara hizkuntzen arteko edo hizkuntza baten dialektoen arteko dibertsitateaz. Horrela deskubrituko ditugu gure hizkuntzaren ezaugarriak, bestela agian ez litzateke inor konturatuko [...], batez ere ezaugarri hauek hizkera arruntarenak baldin badira.']

(Rigau 2004: 25)

«Al cap i a la fi, l'estudi del grau de diversitat que poden presentar les diferents llengües i els seus parlars és el camí per avançar en el coneixement de la facultat humana del llenguatge."

['Azken finean, hizkuntza desberdinetan eta beren hiztunengan aurki dezakegun dibertsitatearen azterketa da gizakion hizkuntza gaitasunaren ezagutzan aurrera egiteko bidea.']

(Rigau 1998: 80)

Bukatzeko, artikulu honetan, katalanaren dialekto desberdinetan aurki ditzakegun desberdintasun sintaktikoak deskribitzeaz haratago, askotan hizkuntza desberdinek bariazio puntu komunak dituztela erakusteko helburuarekin, konparazio interlinguistikoa ere eskeini nahi izan dugu. Izan ere, ez dugu ahaztu behar, bariazio sintaktikoaren ikerketaren helburua dela, ikuspuntu unibertsal batetik, munduko hizkuntzen bariazio sintaktiko ereduen funtzionamendua azaltzen duten mekanismoak esplikatzea. Ekarpen xume honekin lagundu izana espero dugu. 


\section{Erreferentziak}

Batlle, Mar (2002): L’expressió dels tempos compostos en la veu mitjana i la passiva pronominal. Barcelona: Publicacions de l'Abadia de Montserrat.

Bılous, Rostyslav (2011): Transitivité et marquage d'objet différentiel. Doktore-tesia, University of Toronto.

BLumE, Kerstin (1998): «A contrastive analysis of interaction verbs with dative complements», Linguistics 36:2, 253-280.

Creissels, Denis \& Céline Mounole (2012): Non-canonical valency patterns in Basque, variation and evolution. Ms., 45th Annual Meeting of the Societas Linguistica Europaea. Workshop Contrastive studies of verbal valency in European languages, Stockholm University.

CReISSELS, Denis (2008): «Direct and indirect explanations of typological regularities: The case of alignment variations», Folia Linguistica, 42:1, 1-38.

EtXepare, Ricardo (2003): «Valency and Argument Structure in the Basque Verb», José Ignacio Hualde \& Jon Ortiz de Urbina (ed.): A Grammar of Basque. Berlin: Mouton, 363-425.

Fernández, Beatriz \& Jon Ortiz de Urbina (2010): Datiboa hiztegian. Bilbo: EHUko Argitalpen Zerbitzua.

Fernández, Beatriz \& Jon Ortiz de Urbina (2012): «Dative (first) complements in Basque», Ernestina Carrilho \& Beatriz Fernández (ed.): Syntactic microvariation in Westmost European Languages. [Journal of Portuguese Linguistics (Special Issue) 11:1.] Lisboa: Ediçoes Colibrí, Universidade de Lisboa, 83-98.

Fernández-Ordóñez, Inés (1999): «Leísmo, laísmo y loísmo», Ignacio Bosque \& Violeta Demonte (ed.): Gramática Descriptiva de la Lengua Española, vol. I. Madrid: EspasaCalpe, 1317-1397.

Generalitat de Catalunya (2013): Els usos lingüístics de la població de Catalunya. Principals resultats de l'Enquesta d'usos lingüistics de la població. http://lengua.gencat.cat/ permalink/c227a7d6-5382-11e4-8f3f-000c29cdf219

IDESCAT (2014): Ús i coneixement del català (2013). Dossiers Idescat, z. 17, 2014ko abendua. http://www.idescat.cat/cat/idescat/publicacions/cataleg/pdfdocs/dossier17.pdf

LedGEWAy, Adam (2000): A Comparative Syntax of the Dialects of Southern Italy: A Minimalist Approach. Oxford: Blackwell.

Ledgeway, Adam (2009): Grammatica diacronica del napoletano. Tübingen: Max Niemeyer Verlag.

LLoP, Ares (2016): «La negació en els parlars pirinencs centrals. Sintaxi de la marca emfàtica cap», Llengua \& Literatura, 26.

Llop, Ares (prestatzen): Qüestions de microvariació sintàctica: quantificació i negació. Doktoretesia, Universitat Autònoma de Barcelona.

McFadden, Thomas (2004): The Position of Morphological Case in the Derivation: A Study on 
the Syntax-Morphology Interface. Doktore-tesia, University of Pennsylvania.

Morant, Marc (2008): L'alternança datiu/acusatiu en la recció verbal catalana. Doktore-tesia, Universitat de València.

Mounole, Céline (2012): «The evolution of transitive verbs in Basque and the emergence of dative-marked patients», Gilles Authier \& Katharina Haude (ed.): Ergativity, Valency and Voice. Berlin: Mouton de Gruyter, 355-380.

OdRIA, Ane \& Ane BeRRO (2011): Subject and object marking alternation in bivalent predicates: dialectal evidence from Basque. Ms., Typology and Variation: New trends in syntactic research, Helsinki.

Pineda, Anna (2012): «Transitividad y afectación en el entorno lingüístico romance y eusquérico», Xulio Viejo (ed.): Estudios sobre variación sintáctica peninsular. Oviedo: Trabe/Seminariu de Filoloxía Asturiana de la Universidad de Oviedo, 31-73.

PinedA, Anna (2013a): «Double object constructions and dative/accusative alternations in Spanish and Catalan: a unified account». Borealis: An International Journal of Hispanic Linguistics, 2:1, 57-115.

PINEDA, Anna (2013b): «Romance double object constructions and transitivity alternations», Enrico Boone, Martin Kohlberger \& Maartje Schulpen (ed.): XX ConSOLE Proceedings, 20th Conference of the Student Organization of Linguistics in Europe. Leiden: Leiden University, 185-211.

PinedA, Anna (2014a): «What lies behind dative/accusative alternations in Romance», Stefania Marzo \& Karen Lahousse (ed.): Romance Languages and Linguistic Theory 2012. Amsterdam/Philadelphia: John Benjamins, 123-139.

PINEDA, Anna (2014b): Les fronteres de la intransitivitat pura. Estudi dels aplicatius en llengües romàniques i basc. Doktore-tesia, Universitat Autònoma de Barcelona.

Ramos, Joan Rafel (2005a): «Les alternances acusatiu/datiu: perspectiva normativa i dialectal», Jornades de la Secció filològica de l'Institut d'Estudis Catalans a l'Institut Interuniversitari de Filologia Valenciana. Barcelona: Institut d'Estudis Catalans, Institut Interuniversitari de Filologia Valenciana, 151-159.

RAmos, Joan Rafel (2005b): «El complement indirecte: l'alternança datiu / acusatiu», Estudis romànics / publicats a cura de A.M. Badia i Margarit i Joan Veny, vol. 27, 94-111.

Rigau, Gemma (1992): «Aspects of Catalan Dialectal Syntax. Unaccusative Sentences and Related Structures». Journal of Hispanic Research, vol. II, 2 (1992-1993), 315-329.

RigAU, Gemma (1997a): «Locative sentences and related constructions in catalan: ésser / haver alternation». Amaya Mendikoetxea, Myriam Uribe-Etxebarria, (ed.): Theoretical issues at the morphology-syntax interface. Bilbao; Donostia - San Sebastián: Euskal Herriko Unibertsitatea; Gipuzkoa Foru Aldundia, 395-421.

Rigau, Gemma (1997b): «Sintaxi i variació dialectal: les construccions locatives». Maria Rosa Lloret, Emili Boix, Mercè Lorente, Lluís Payrató, Maria Pilar Perea (ed.): Anàlisi de la variació lingüística. Barcelona: Promocions i Publicacions Universitàries, Universitat de Barcelona, 179-201. 
Rigau, Gemma (1998): «La variació sintàctica: uniformitat en la diversitat», Caplletra, 25, 63-82.

Rigau, Gemma (2004): «El quantificador focal pla: un estudi de sintaxi dialectal», Caplletra, 36, 25-54.

SÁez, Luis (2009): «Applicative phrases hosting accusative clitics». Ronald P. Leow, Héctor Campos \& Donna Lardiere (ed.): In Little words: Their history, phonology, syntax, semantics, pragmatics, and acquisition. Washington: Georgetown University Press, 6173.

SolÀ, Joan (1973): Estudis de sintaxi catalana. Vol. II. Barcelona: Edicions 62. (Llibres a l'abast, 105).

SOLÀ, Joan (1987): Qüestions controvertides de sintaxi catalana. Barcelona: Edicions 62. (Llibres a l'abast, 229).

SolÀ, Joan (1994): Sintaxi normativa: estat de la qüestió. Barcelona: Empúries.

SoLÀ, Joan (1999): Parlem-ne. Converses lingüístiques. Barcelona: Proa.

Troberg, Michelle Ann (2008): Dynamic Two-place Indirect Verbs in French: A Synchronic and Diachronic Study in Variation and Change of Valence. Doktore-tesia, University of Toronto.

VenY, Joan (1983): Els parlars catalans. Palma de Mallorca: Editorial Moll. 